\title{
Isolated ACTH deficiency
}

\author{
Metabolic and endocrine studies in a 7-year-old boy
}

\author{
A. AYNSLEY-GREEN, M. W. MONCRIEFF, S. RATTER, C. R. BENEDICT, C. N. STORRS, \\ AND R. H. WILKINSON \\ From the Departments of Paediatrics, Clinical Biochemistry, and Clinical Pharmacology, Radcliffe \\ Infirmary, Oxford; and Department of Chemical Pathology Research, St. Bartholomew's Hospital, London
}

SUMMARY Metabolic and endocrine studies on a 7-year-old boy who presented with hypoglycaemic convulsions are reported in detail, proving the diagnosis of isolated ACTH deficiency - a rare cause of hypoglycaemia in childhood. Adrenaline secretion during insulin-induced hypoglycaemia was reduced. Low blood alanine levels occurred during starvation-induced hypoglycaemia, together with raised total blood ketone bodies; blood glucose did not increase adequately after oral alanine at this time. Hypoglycaemia in isolated ACTH deficiency appears to be due to a combination of impaired alanine mobilisation and a decreased rate of gluconeogenesis.

Isolated deficiency of ACTH is a rare disorder in adults and even more uncommon in childhood. Thus of the 25 cases of the disorder reported previously*, only one was a child under 15 years of age (Hung and Migeon, 1968). In many of the other cases it was not proved conclusively that the defect was isolated and not part of a more generalised pituitary abnormality.

We now report metabolic and endocrine studies on a 7-year-old boy with isolated ACTH deficiency who presented with hypoglycaemia. The studies prove the isolated nature of the defect and provide further information on the mechanism of the hypoglycaemia in the condition.

\section{Case report}

This 7-year-old boy, previously in good health, was admitted to hospital because of a convulsion. $\mathrm{He}$ was unconscious, and pyrexial, but no other abnormal physical signs were found on examination; in particular, his blood pressure was $120 / 60 \mathrm{mmHg}$. Capillary blood failed to cause any colour change with a Dextrostix, and his blood glucose concentration was only $1.66 \mathrm{mmol} / 1(30 \mathrm{mg} / 100 \mathrm{ml})$. He regained consciousness after treatment with intravenous glucose but remained confused and irritable for a few days. All subsequent blood glucose concentrations however were normal on intravenous

*A list of these references can be obtained from the authors. Received 26 September 1977 glucose and then on a normal diet. His weight was on the 50th centile for his age, and his height on the 75 th centile.

He recovered rapidly and was discharged home physically and mentally normal 10 days after admission. Plasma electrolyte concentrations had been normal throughout his admission, but slightly raised levels of plasma SGOT and blood ammonia (240 IU/1 and $90 \mu \mathrm{mol} / 1(126 \mu \mathrm{g} / 100 \mathrm{ml})$ respectively) led to a consideration of the diagnosis of Reye's syndrome.

Two months later he had another convulsion, a Dextrostix failed to record, and he again responded to intravenous glucose. Further investigations into the cause of the recurrent hypoglycaemia showed low fasting plasma cortisol and ACTH levels. Detailed investigations of adrenal and pituitary function were performed which confirmed that he had an isolated ACTH deficiency. He was treated with hydrocortisone $5 \mathrm{mg}$ twice a day and has remained in good physical and mental health with no further hypoglycaemic convulsions.

\section{Methods}

All blood samples were drawn through an indwelling venous cannula. Plasma samples were obtained by immediate centrifugation of heparinised whole blood at $4^{\circ} \mathrm{C}$, and were stored at $-20^{\circ} \mathrm{C}$ until assayed.

Plasma immunoreactive growth hormone (GH) was measured by double antibody immunoassay using purified human GH (Dr P. J. Lowry) as 
standard and tracer. Human luteinising hormone (LH) was measured by double antibody immunoassay using MRC 68/40 LH as standard and IRC 2/69 LH (Dr A. Hartree) as tracer; follicle stimulating hormone (FSH) was measured in a similar system using MRC 69/104 FSH as standard and FSH CPD 514 (Professor W. Butt) as tracer. Plasma immunoreactive thyroid stimulating hormone (TSH) was measured by double-antibody immunoassay using MRC 68/38 TSH as standard and purified human TSH (Kabi) as tracer. Human prolactin was measured by double antibody radioimmunoassay and results expressed in terms of the MRC human prolactin standard A. ACTH was measured by bioassay (Chayen et al., 1972) and by radioimmunoassay (Rees et al., 1971). The laboratory performing the above assays is a member of the Supra-regional Assay Service Hormone Quality Control Scheme.

Plasma cortisol was measured by a competitive protein binding method; plasma adrenaline and noradrenaline were measured by a radioenzymatic method (Hortnagel et al., 1978), the plasma being derived from whole blood added immediately to an ice-cold heparinised tube containing solid reduced glutathione. Plasma aldosterone and plasma renin activity were assayed as reported by Dillon and Ryness (1975). Total 17-oxosteroids and 17-oxogenic steroids and pregnanetriol were measured in urine by standard methods; urinary free cortisol was measured by a competitive protein binding method.

Blood $(0 \cdot 5-1 \cdot 0 \mathrm{ml})$ was added to $5 \mathrm{ml}$ ice-cold $10 \%$ perchloric acid, and the neutralised supernatant was used for assay of intermediary metabolites. Glucose, lactate, pyruvate, acetoacetate, $3 \beta$-hydroxybutyrate, and alanine were determined by standard enzymatic techniques (Bergmeyer, 1974).

The ability of the pituitary to secrete LH, FSH, and TSH was assessed by measuring these hormones, together with prolactin, before and after the combined intravenous injection of $100 \mu \mathrm{g}$ luteinising hormone-releasing hormone (LHRH) (Ayerst) and $200 \mu \mathrm{g}$ thyrotrophin-releasing hormone (TRH) (Roche). 90 minutes later, insulin, $0.05 \mathrm{U} / \mathrm{kg}$, was injected, and the levels of glucose, GH, cortisol, catecholamines, renin activity, and aldosterone were measured. The response of the adrenal cortex to exogenous ACTH was assessed by measuring urinary freecortisol, 17-oxosteroids, and 17-oxogenic steroids after injections of $1 \mathrm{mg}$ of tetracosactrin zinc (Depot Synacthen) given on alternate days for 3 doses.

Blood glucose and intermediary metabolites were measured before and after meals and during prolonged starvation. His ability to synthesise glucose by gluconeogenesis was measured by giving oral alanine, $500 \mathrm{mg} / \mathrm{kg}$, when hypoglycaemia developed during starvation.

\section{Results}

Hypothalamo-pituitary function. The results of administration of LHRH and TRH are given in Table 1. Basal levels of LH, FSH, and TSH were normal and increased after stimulation. Basal plasma prolactin was slightly raised (normal adult basal value $<360 \mathrm{mU} / \mathrm{l}$ ), probably due to stress, but the response to TRH was normal. The results of the insulin tolerance test are shown in Table 2. There was an adequate increase in GH secretion after insulin but the basal concentrations of ACTH and cortisol were low and did not increase despite symptomatic hypoglycaemia requiring intravenous glucose administration.

Adrenocortical function. The results of urinary steroid measurements before and after three injections of depot ACTH are shown in Table 3. The basal excretion of cortisol was low $(60 \mathrm{nmol} / 24 \mathrm{~h} ; 16.6$ $\mu \mathrm{g} / 24 \mathrm{~h}$ ) but it then increased markedly to $>800$ $\mathrm{nmol} / 24 \mathrm{~h}(220 \mu \mathrm{g} / 24 \mathrm{~h})$, showing that the adrenal cortex responded adequately to prolonged stimulation. The excretion of pregnanetriol was not raised, thus excluding congenital adrenal hyperplasia. Plasma aldosterone measured in a sample drawn 30 minutes after insulin during the insulin tolerance test was $266 \mathrm{pmol} / \mathrm{l}$ (normal range for age 28-616 pmol/1).

Table 1 Plasma levels of $L H, F S H, T S H$, and prolactin before and after $L H-R H / T R H$

\begin{tabular}{rllll}
\hline $\begin{array}{l}\text { Time } \\
(\min )\end{array}$ & $\begin{array}{l}\text { LH } \\
(U / l)\end{array}$ & $\begin{array}{l}\text { FSH } \\
(U / l)\end{array}$ & $\begin{array}{l}\text { TSH } \\
(\mathrm{mU} / l)\end{array}$ & $\begin{array}{l}\text { Prolactin } \\
(\mathrm{mU} / l)\end{array}$ \\
\hline-30 & 1.9 & 0.4 & 5.7 & 460 \\
0 & 2.5 & 0.7 & - & 260 \\
20 & 4.5 & 0.7 & 12.9 & 1140 \\
30 & 3.3 & 1.0 & 11.5 & -1060 \\
60 & 2.5 & 1.0 & 10.7 & 1060 \\
\hline
\end{tabular}

Table 2 Levels of blood glucose and plasma $G H$, cortisol, ACTH, and catecholamines before and after intravenous insulin $(0.05 \mathrm{U} / \mathrm{kg})$

\begin{tabular}{|c|c|c|c|c|c|c|}
\hline $\begin{array}{l}\text { Time } \\
\text { (min) }\end{array}$ & $\begin{array}{l}\text { Glucose } \\
(\mathrm{mmol} / \mathrm{l})\end{array}$ & $\begin{array}{l}G H \\
m U / l\end{array}$ & $\begin{array}{l}\text { Cortisol } \\
(\mathrm{nmol} / \mathrm{l})\end{array}$ & $\begin{array}{l}A C T H \\
(n g / l)\end{array}$ & $\begin{array}{l}\text { Adrenaline } \\
(\mu \mathrm{g} / l)\end{array}$ & $\begin{array}{l}\text { Noradrena- } \\
\text { line } \\
(\mu \mathrm{g} / l)\end{array}$ \\
\hline $\begin{array}{r}0 \\
15 \\
* 30 \\
60 \\
90\end{array}$ & $\begin{array}{l}3 \cdot 56 \\
1 \cdot 91 \\
1 \cdot 27 \\
2 \cdot 50 \\
2 \cdot 30\end{array}$ & $\begin{array}{l}15 \\
12 \\
20 \\
13 \\
23\end{array}$ & $\begin{array}{l}220 \\
190 \\
180 \\
180 \\
200\end{array}$ & $\begin{array}{l}<15 \\
<15 \\
<15 \\
<15 \\
<15\end{array}$ & $\begin{array}{l}0.15 \\
0.05 \\
0.42 \\
0.40 \\
0.06\end{array}$ & $\begin{array}{l}0.23 \\
0 \cdot 16 \\
1 \cdot 39 \\
1 \cdot 12 \\
0.92\end{array}$ \\
\hline $\begin{array}{r}\text { Norm } \\
\text { Bas } \\
\text { Pea }\end{array}$ & $\begin{array}{l}\text { al } \\
\text { l range } \\
\text { range }\end{array}$ & $\overline{>20}$ & $\begin{array}{l}150-700 \\
>600\end{array}$ & $\begin{array}{l}15-80 \\
100-300\end{array}$ & $\begin{array}{l}0.02-0.25 \\
1.0-1 \cdot 50\end{array}$ & $\begin{array}{l}0.20-0.65 \\
0.80-1 \cdot 40\end{array}$ \\
\hline
\end{tabular}


Table 3 Urinary free cortisol, 17-oxosteroids, and 17-oxogenic steroids before and after depot Synacthen (figures are means of two 24-hour collections)

\begin{tabular}{ccccc}
\hline & $\begin{array}{l}\text { Free } \\
\text { cortisol } \\
(\mathrm{nmol} / 24 \mathrm{~h})\end{array}$ & $\begin{array}{l}\text { 17-oxo- } \\
\text { steroids } \\
(\mu \mathrm{mol} / 24 \mathrm{~h})\end{array}$ & $\begin{array}{l}\text { 17-oxogenic } \\
\text { steroids } \\
(\mu \mathrm{mol} / 24 \mathrm{~h})\end{array}$ & $\begin{array}{l}\text { Pregnanetriol } \\
(\mu \mathrm{mol} / 24 \mathrm{~h})\end{array}$ \\
\hline $\begin{array}{c}\text { Before days } \\
1 \text { and 2 }\end{array}$ & 60 & $10 \cdot 5$ & $7 \cdot 5$ & \\
$\begin{array}{c}\text { After days } \\
2 \text { and 3 }\end{array}$ & 520 & $9 \cdot 5$ & $28 \cdot 5$ & \\
4 and 5 & 550 & 39 & 20 & $1 \cdot 2$ \\
6 and 7 & $>800$ & 23 & 110 & \\
$\begin{array}{c}\text { Normal } \\
\text { Basal }\end{array}$ & $<280$ & $1-10$ & $2 \cdot 1-38$ & $<3$ \\
Peak & $>800$ & $>20$ & $>90$ & \\
\hline
\end{tabular}

Conversion: SI to traditional units-Cortisol: $1 \mathrm{nmol} / 24 \mathrm{~h} \approx 0.27 \mu \mathrm{g} /$ $24 \mathrm{~h}$. 17-oxo and oxogenic steroids: $1 \mu \mathrm{mol} / 24 \mathrm{~h} \approx 0.288 \mathrm{mg} / 24 \mathrm{~h}$. Pregnanetriol: $1 \mu \mathrm{mol} / 24 \mathrm{~h} \approx 0.337 \mathrm{mg} / 24 \mathrm{~h}$.

Basal plasma renin activity was $700 \mathrm{ng} \mathrm{AI} / 1$ per $\mathrm{h}$ (normal range for age 131-834 $\mathrm{ng} \mathrm{AI} / 1$ per h) rising normally to a peak value of $2760 \mathrm{ng} \mathrm{AI} / 1 \mathrm{pr} \mathrm{h}$ 30 minutes after insulin.

Adrenomedullary function. The increase in plasma adrenaline and noradrenaline during insulin-induced hypoglycaemia is shown in Table 2 . The adrenaline response was delayed and the peak lower than expected.

Metabolic studies. Changes in inertmediary metabolites during a 30-hour period are shown in the Fig. Blood levels of glucose, lactate, and total ketone bodies (the sum of acetoacetate and 3-hydroxybutyrate) were normal while the patient was feeding, but after 12 hours of starvation the blood glucose level fell to $1.5 \mathrm{mmol} / 1(27 \mathrm{mg} / 100 \mathrm{ml})$ associated with an abnormally low level of alanine $(0.055 \mathrm{mmol} / \mathrm{l}$;

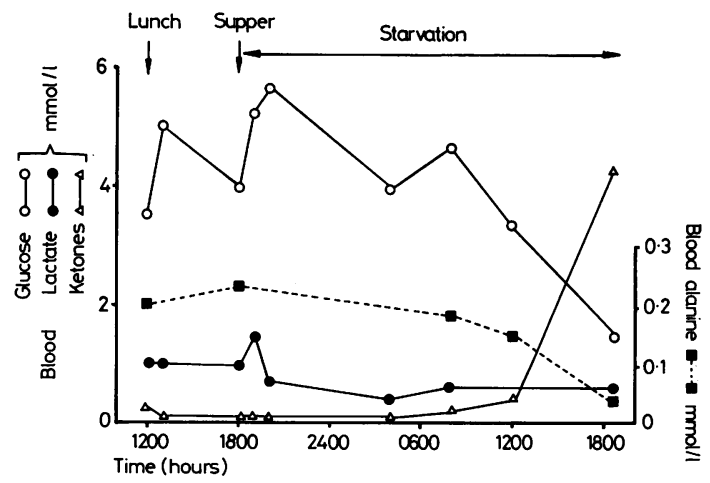

Fig. Metabolic response to starvation in isolated $A C T H$ deficiency. Conversion: SI to traditional unitsglucose: $1 \mathrm{mmol} / \mathrm{l} \approx 18 \mathrm{mg} / 100 \mathrm{ml}$. Lactate: $1 \mathrm{mmol} / \mathrm{l}$ $\approx 9 \mathrm{mg} / 100 \mathrm{ml}$. Ketones: $1 \mathrm{mmol} / \mathrm{l} \approx 10.2 \mathrm{mg} /$ $100 \mathrm{ml}$. Alanine : $1 \mathrm{mmol} / \mathrm{l} \approx 8.91 \mathrm{mg} / 100 \mathrm{ml}$. normal adult fasting range $0 \cdot 18-0 \cdot 25 \mathrm{mmol} / \mathrm{l})$. At this time the total blood ketone body levels had increased markedly to $4.4 \mathrm{mmol} / \mathrm{l}$. Oral alanine was then given, but 30 minutes later the blood glucose value had increased only to $2 \cdot 25 \mathrm{mmol} / 1(40 \cdot 5 \mathrm{mg} /$ $100 \mathrm{ml}$ ), and intravenous glucose had to be given to prevent coma.

\section{Discussion}

The studies performed on this child prove that he has an isolated deficiency of ACTH. The cause of the condition is unknown. Hung and Migeon (1968) suggested that it is due to a discrete hypothalamic lesion causing impaired synthesis of corticotrophin releasing hormone. This suggestion is supported by Martin and Martin (1971) who reported briefly in an abstract 3 children with apparent ACTH deficiency who did not increase their plasma ACTH during insulin-induced hypoglycaemia, but who did so after lysine vasopressin. The latter is thought to have a direct effect on pituitary release of ACTH, but final proof of a hypothalamic defect will only be possible if corticotrophin releasing hormone can be made available for clinical use.

The clinical features of this disease have not been defined in children. Adults show the typical features of adrenocortical insufficiency, but usually lack the pigmentation found in Addison's disease (Odell, 1966). The only other child reported with the disease (Hung and Migeon, 1968) presented, as did our case, with hypoglycaemia, and also had no impairment in linear growth or bony maturation. The present child was insulin-sensitive, for he developed severe hypoglycaemia after half the usual dose given in the insulin tolerance test. This sensitivity indicates a defect in the counter-regulatory mechanisms which maintain normoglycaemia. One defect demonstrated in addition to a failure to increase cortisol is the delayed and diminished secretion of adrenaline in response to hypoglycaemia. This abnormality was also found in the child reported by Hung and Migeon (1968), who suggested that the decreased intraadrenal concentration of cortisol as a result of ACTH deficiency decreased the activity of the enzyme phenylethanolamine - $\mathbf{N}$ - methyl-transferase, which promotes the formation of adrenaline from noradrenaline.

Impaired adrenaline and cortisol release during hypoglycaemia do not by themselves explain completely our patient's failure to maintain normoglycaemia. Our metabolic studies provide further information on the inter-relation of adrenal function and intermediary metabolism.

The child developed low circulating concentrations of alanine, an important gluconeogenic precursor, 
during starvation. Low alanine levels have also been reported in children with 'ketotic hypoglycaemia' (Haymond et al., 1974) and glycogen synthetase deficiency (Aynsley-Green et al., 1977). Presumably the low circulating alanine is due to decreased mobilisation of the amino acid from peripheral muscle, which may be explained either by a failure of adrenaline stimulated release (Sizonenko et al., 1973) or an inhibition of alanine formation by the high concentrations of ketone bodies (Sherwin et al., 1975). We prefer the former explanation in this child in view of the demonstrated inadequate adrenomedullary responsiveness.

A further metabolic abnormality is suggested, however, by the failure to increase blood glucose adequately by giving oral alanine when hypoglycaemic. This indicates that the rate of gluconeogenesis is decreased in isolated ACTH deficiency, presumably due to the low concentrations of cortisol and adrenaline. We suggest therefore that fasting hypoglycaemia in this condition is due to a combination of decreased availability of alanine and a decreased rate of gluconeogenesis.

The findings of a low blood alanine level, high blood ketone bodies, and hypoglycaemia are characteristic of 'ketotic hypoglycaemia'. We suggest that plasma cortisol should be measured in children with hypoglycaemia in order to exclude adrenocortical hypofunction.

We thank Dr L. H. Rees for pituitary hormone measurements, Dr D. H. Williamson for blood alanine measurements, Dr M. Dillon for plasma aldosterone and renin activity measurements, and Mrs P. Jenkins for skilled technical assistance.

\section{References}

Aynsley-Green, A., Williamson, D. H., and Gitzelmann, R. (1977). Hepatic glycogen synthetase deficiency: definition of syndrome from metabolic and enzyme studies on a nine-year-old girl. Archives of Disease in Childhood, 52, 573-579.
Bergmeyer, H. U. (1974). Methods of Enzymatic Analysis. Academic Press, New York.

Chayen, J., Loveridge, N., and Daly, J. R. (1972). A sensitive bioassay for adrenocorticotrophic hormone in human plasma. Clinical Endocrinology, 1, 219-233.

Dillon, M. J., and Ryness, J. M. (1975). Plasma renin activity and aldosterone concentration in children. British Medical Journal, 4, 316-319.

Haymond, M. W., Karl, I. E., and Pagliara, A. S. (1974). Ketotic hypoglycemia: an amino acid substrate limited disorder. Journal of Clinical Endocrinology and Metabolism, 38, 521-530.

Hortnagel, H., Benedict, C. R., Grahame-Smith, D. G., and McGrath, B. (1977). A sensitive radioenzymatic method for adrenaline and noradrenaline in plasma. British Journal of Clinical Pharmacology, 4, 553-558.

Hung, W., and Migeon, C. J. (1968). Hypoglycemia in a two year old boy with adrenocorticotropic hormone (ACTH) deficiency (probably isolated) and adrenal medullary unresponsiveness to insulin-induced hypoglycemia. Journal of Clinical Endocrinology, 28, 146-152.

Martin, M. M., and Martin, A. L. A. (1971). Idiopathic hypoglycemia-a defect in hypothalamic ACTH-releasing factor scretion. (Abst.) Pediatric Research, 5, 396.

Odell, W. D. (1966). Isolated deficiencies of anterior pituitary hormones. Journal of the American Medical Association, 197, 1006-1016.

Rees, L. H., Cook, D. M., Kendall, J. W., Allen, C. F., Kramer, R. M., Ratcliffe, J. G., and Knight, R. A. (1971). A radioimmunoassay for rat plasma ACTH. Endocrinology, 89, 254-261.

Sherwin, R. W., Hendler, R. G., and Felig, P. (1975). Effect of ketone infusions on amino acid and nitrogen metabolism in man. Journal of Clinical Investigation, 55, 1382-1390.

Sizonenko, P. C., Paunier, L., Vallotton, M. B., Cuendet, G. S., Zahnd, D., and Marliss, E. B. (1973). Response to 2deoxy-D-glucose and to glucagon in 'ketotic hypoglycemia' of childhood: evidence for epinephrine deficiency and altered alanine availability. Pediatric Research, 7, 983993.

Correspondence to Dr A. Aynsley-Green, University Department of Paediatrics, The John Radcliffe Hospital, Oxford OX3 9DU. 